\title{
Kairiojo plaučio apatinės skilties hipoplazija, diagnozuota astma sergančiai pacientei
}

\author{
Klinikinis atvejis
}

\author{
Iveta Skurvydienè \\ Tauragės apskrities ligoninės Konsultacijų poliklinika
}

Plaučių hipoplazija yra plaučių anomalija, kuriai būdingas nevisavertiškai susiformavęs plaučių audinys, dažniausiai - vieno plaučio. Lgimta (pirminè šeiminè) plaučių hipoplazija yra reta liga, plačiai aprašyta medicinos literatūroje. Ji pasireiškia naujagimystėje ir lemia didelį pacientų mirštamumą (71-95 proc.). Mokslinių straipsnių apie igytą plaučių hipoplaziją medicinos literatūroje labai maža, 0 itin retos yra klinikinių atvejų publikacijos, kuriose aprašyti astma sergančių vyresnio amžiaus pacientų plaučių hipoplazijos atvejai [1]. Šiame straipsnyje pristatomas retas klinikinis atvejis padès gydytojams susipažinti su plaučių hipoplazijos klinikine išraiška ir poveikiu ligonio gyvenimo kokybei.

Šio straipsnio herojè - $17 \mathrm{~m}$. pacientè, serganti nuolatine alergine astma. Nuo 9 metu ji yra įtraukta ị vaiku pulmonologo įskaitą. Nors paciente buvo gydoma sudètiniais vaistais nuo astmos, atitinkančiais jos ligos sunkumo pakopą, patenkinamai kontroliuoti astmos simptomų nesisekè 2 metus, be to, ji kasmet sirgdavo úmine bronchopneumonija. Siekiant patikslinti ligos diagnozę, pirmiausia buvo peržiūrèta ligos anamnezè bei eigos ypatumai ir taikyti diagnostikos bei gydymo metodai.

Susipažinus su šeimos gydytojo pateiktais pacientès sveikatos ambulatorinès kortelès duomenimis, sužinota, kad pacientė gimé po normalaus néštumo ir gimdymo, gimimo svoris - $3650 \mathrm{~g}$, pagal Apgar įvertinta 8-9 balais. Pirmomis gyvenimo dienomis susirgo naujagimiu hemolizine liga dèl motinos ir vaisiaus kraujo grupių nesutapimo (ABO konfliktas). Pacientès tėvo broliu vaikai serga alerginiu rinitu, alergine astma. Pacientė motinos pienu buvo maitinama 9 mèn., jos ūgis ir svoris augo normaliai.

\section{LIGOS ISTORIJA}

\section{Nuo 1 metụ iki 5 metụ amžiaus}

- Iki 1 metụ ligoninèje gydyta 3 kartus: 3 mènesių sirgo S. aureus sukeltu ūminiu enteritu, 6 mèn. - virusine sloga ir vidurinès ausies uždegimu, o 10 mèn. - üminiu obstrukciniu bronchitu, kuris per 24 val. nuo ligos pradžios pasireiške krepituojančiais karkalais plaučiuose.

- 1 m. 4 mèn. amžiaus susirgo ūmine virusine kvėpavimo takų infekcija, po kurios 1 mėnesị laikèsi sausas naktinis kosulys.

- $1 \mathrm{~m} .10$ mèn. amžiaus susirgo ūmine bronchopneumonija, plaučiu rentgenogramos duomenys: deformuotas plaučių piešinys, kairiajame plautyje - sumažèjusio oringumo ir hiperinfliacijos ploteliai. Trachejos aspirato pasèlyje išauginta $S$. aureus, Klebs. aerogenes.

- Pacienté ligoninëje buvo gydoma 1 mènesĭ, tačiau karkalai plaučiuose tebesilaikè. Perkeltos ị Vaikụ reabilitacijos ligoninę pacientès kairiajame plautyje girdèti sausų ir drègnų karkalų, skrepliu pasèlyje išauginta S. aureus ir streptokokų.

- Dèl neišnykstančių vidutinio stambumo drègnu karkalų abiejuose plaučiuose perkelta ị Vilniaus universiteto Vaiku ligoninę. Atlikus bronchoskopiją, kairiajame pagrindiniame bronche rasta pülingo sekreto, bakteriologiniame pasèlyje bakterijų neišaugo. Konsultuota tuometinès Vilniaus universitetinès Vaiku ligoninès profesorès - ịtartos igimtos bronchektazès, paskirtas gydymas antibiotikais, mukolitikais.

- 2 m. 2 mèn. amžiaus susirgo ūmine virusine kvejpavimo taku infekcija, kurios pradžioje išryškejjo nak- 
tinis kosulys, švokštimas, sausi karkalai plaučiuose, paskirtas gydymas teofilinu (Teopek), acetilcisteinu, klenbuteroliu, ketotifenu.

- Tarp 2,5 ir 5 m. amžiaus pacientè 4 kartus sirgo ūmine kvėpavimo takų infekcija be bronchų obstrukcijos požymių ir 4 kartus - su bronchų obstrukcijos požymiais.

\section{Nuo 5 metų iki 9 metų amžiaus}

- Dèl dažnų obstrukcinių bronchitų 6 metų pacientė konsultuota alergologo, atlikti odos dūrio mėginiai nebuvo informatyvūs, tačiau rekomenduota pacientę stebèti dèl galimos astmos.

- 6 m. 4 mèn. pacientei alergologo konsultacijos metu atlikti odos dūrio méginiai, nustatytas įsijautrinimas dulkių erkutèms, pelynui, plunksnoms, diagnozuota endogeninè astma, alerginis rinitas, paskirtas gydymas fenoteroliu su dinatrio kromoglikatu (Ditec), o salbutamoliu (Ventolin) - pagal poreikị.

- 6 m. 4 mén. po dusulio priepuoliu gydyta sanatorijoje, pirmą kartą atlikta spirometrija: $\mathrm{FEV}_{1}-77$ proc. FVC - 65 proc. PEF - 77 proc., bronchuc plètimo mėginys neatliktas.

- 6 m. 9 mèn. paskirtas gydymas salmeterolio (Serevent) $25 \mu \mathrm{g} 2 \mathrm{k}$. per dieną, tačiau vis kartojasi naktinis kosulys, švokštimas.

- 7,5 m. po astmos paūmèjimo paskirtas 1 mẻn. gydymo kursas montelukasto natrio druskos (Singulair) $5 \mathrm{mg}$ per dieną ir salbutamoliu - pagal poreikị.

- $8 \mathrm{~m}$. amžiaus pacientè susirgo ūmine bronchopneumonija, siųsta vaikų pulmonologo konsultacijos. Atlikto bendrojo IgE tyrimo rezultatas - 96,44 TV/ml (norma - iki 90). Klinikinè diagnozè: mišri astma, nuolatinè, vidutinio sunkumo eiga, J45.8, alerginis rinitas, J30.3. Skirtas 1 mèn. trukmès gydymas salmeterolio/flutikazono propionato (Seretide) 50/100 $\mu \mathrm{g} 2$ inhaliacijomis per dieną.

- 8 m. 2 mèn. pacientė konsultuota alergologo, atlikti odos dūrio méginiai, nustatyta alergija dulkių erkutèms, motiejukui, pelynui.

Papildoma klinikinè diagnozè: egzogeninè astma, nuolatinè vidutinio sunkumo eiga, J45.0, polenozé, J30.1.

- $9 \mathrm{~m}$. po ūminès bronchopneumonijos ir astmos paūmejjimo konsultuota vaiku pulmonologo. Spirometrijos duomenys: $\mathrm{FEV}_{1}-79$ proc., FVC - 73 proc., PEF - 54 proc. (+21 proc. po salbutamolio). Skirtas gydymas budezonidu (Pulmicort) $200 \mu \mathrm{g} 2 \mathrm{k}$. per dieną, montelukasto natrio druskos (Singulair) $5 \mathrm{mg}$ kartą per dieną, salbutamoliu - pagal poreikị.

- 9 m. 3 mèn. - vaikú pulmonologo konsultacija. Spirometrijos duomenys: $\mathrm{FEV}_{1}-80$ proc., FVC -70 proc., PEF - 72 proc. Paskirtas gydymas budezonido (Miflonide) $200 \mu \mathrm{g} 2 \mathrm{k}$. per dieną, formoterolio (Foradil) $12 \mu \mathrm{g} 2 \mathrm{k}$. per dieną.

- 9 m. 8 mèn. pacientę vẻl konsultuoja vaikų pulmonologas, nes kartojasi švokštimai, po ūminès kvėpavimo takų infekcijos ilgai laikosi karkalai, greitai pavargsta po fizinio krūvio. Paskirtas gydymas budezonido/formoterolio (Symbicort) 160/4,5 $\mu \mathrm{g} 2$ inhaliacijomis per dieną, mometasono furoato monohidrato (Nasonex) $50 \mu \mathrm{g} 2 \mathrm{k}$. per dieną.

\section{Nuo 10 metų iki 12 metų amžiaus}

- 10-11 m. pacienté patyré du bronchų astmos paūmèjimus, persirgo ūmine bronchopneumonija, vartojo budezonido/formoterolio (Symbicort) 160/4,5 $\mu \mathrm{g} 2$ inhaliacijomis per dieną.

- Būdama 11 metų dèl nepakankamos astmos kontrolès tirta Vilniaus universitetinèje Vaikų ligoninejje. Chloro koncentracija prakaite - $37 \mathrm{mmol} / \mathrm{l}$. Diagnozè: egzogeninè astma, sunki nuolatinè eiga. GERL. Lètinis tonzilitas. Itariama cistinè fibrozè.

- 12 m. amžiaus KMUK Vaikų skyriuje tirta dèl įtariamos cistinès fibrozès ir nepakankamai gero atsako i adekvatu pakopinị astmos gydymą.

\section{Tyrimai atlikti KMUK Vaiku skyriuje}

Plaučiuose alsavimas vezikulinis, birzgiantys karkalai forsuotai iškvepiant. Otorinolaringologo konsultacijos duomenys: II-III ${ }^{\circ}$ adenoidu hipertrofija. Specifiniai kraujo IgE - ìsijautrinimas lateksui, ąžuolo, pelèsio, dulkių erkutès alergenams. Padidèjęs fagocitozès indeksas (11 proc.), tuberkulino mėginys - $12 \mathrm{~mm}$ skersmens papulè. Priekinè plaučiu rentgenograma: pagausėjęs kraujagyslių piešinys, šaknys nestruktūriškos.

Plaučių kompiuterinè tomograma: kairioji krūtinès ląstos pusè mažesnè, plaučiai asimetriški, kairiojo plaučio viršutinè skiltis oringesnè, padidejusios apimties, o apatinè skiltis neoringa, aplastinè, su plačiomis bronchų užuomazgomis, tarpuplautis pasislinkęs i kairę.

Diagnozè: Hypoplasia lobi inferioris pulmonis sinistri, Q33.6. Asthma bronchiale allergicum, cursus moderatus persistens, J45.0. Gydytojų konsiliumo išvada: sunkesnę astmos eigą sąlygoja igimta plaučiu patologija.

Po gydymo antibiotikais atliktas plaučių angiografinis tyrimas, jo išvada: kraujagyslių išsišakojimas normalus. Bronchoskopijos duomenys: nenormaliai atsišakojantys kairiojo plaučio apatiniai skiltiniai bronchai, jie atsišakoja iš vienos vietos. Sprendimas: chirurginis hipoplazinès skilties pašalinimas.

- 12 m. 9 mén. amžiaus pacientei atlikta torakoskopinè operacija, jos metu atidalyta hipoplazinè kairiojo plaučio skiltis, o atliktos torakotomijos metu buvo perrišti, pašalinti nenormaliai atsišakojantys bronchai ir arterijos. Operacijos metu rasta patologija ịvardyta taip: hipoplazinè kairiojo plaučio apatinè skiltis, normaliai atsišakojanti iš plaučio šaknies.

Patologinio histologinio tyrimo išvada: rezekuotame plaučio segmente aktyvus lètinis bronchitas, bronchektazès, visiška atelektazè ir lètinis aktyvus uždegimas bei kraujosruvos.

Išrašomai iš ligoninès pacientei paskirtas astmos gydymas budezonido/formoterolio (Symbicort) 160/4,5 $\mu \mathrm{g} 2$ inhaliacijomis per dieną 6 mèn. laikotarpiui.

\section{Ligos eiga po operacijos}

Praejjus 9-12 mèn. po operacijos, pacientès kvejpavimo funkcijos rodikliu pagerèjimas buvo akivaizdus: atitinka- 
mai FEV ${ }_{1}-83$ proc., FVC - 79 proc., PEF - 79 proc. ir $\mathrm{FEV}_{1}$ - 97 proc., FVC - 87 proc., PEF - 83 proc.

Praejus 4 metams po operacijos, pacientè tebevartoja Symbicort 160/4,5 $\mu \mathrm{g} 2$ inhaliacijomis per dieną iki 7-8 mèn. per metus. Astmos kontrolès tyrimai rodo, kad liga kontroliuojama gerai. Kvèpavimo funkcijos rodikliai yra normalūs, per paskutinius 4 metus pacientè nè karto nesirgo plaučių uždegimu. Mergina lanko kūno kultūros pamokas, muzikos mokykloje mokosi pūsti klarnetą, pamokas mokykloje dažniau praleidžia dèl koncertinių išvykų, o ne dèl kvėpavimo takų ligų.

\section{APTARIMAS}

Medicinos literatūroje plačiau aprašyti igimtos plaučių hipoplazijos atvejai [2, 3]. Remiantis eksperimentinių tyrimų duomenimis, manoma, kad igimtos plaučių hipoplazijos etiologiniai veiksniai gali būti ịvairūs transkripcijos ir augimo faktoriai [4]. Sukauptu patomorfologinių tyrimuc duomenimis, hipoplazinis plautis susideda iš skiauterès, deformuoto bronchų medžio, neišsivysčiusių alveolių ir smulkiųjų plaučių arterijų. Daugiau kaip 50 proc. igimtos plaučių hipoplazijų atvejuc kartu su kvejpavimo takų raidos anomalijomis būna širdies, virškinimo, urogenitalinès sistemos, skeleto anomalijų ir bronchopulmoninių kraujagyslių anomalijų. Kai kurios iš jų, pavyzdžiui, inksto agenezija, gali būti diagnozuojamos atliekant vaisiaus ultragarsinį tyrimą planinio něščiosios patikrinimo metu. Nustačius inksto ageneziją, antenataliniu laikotarpiu galima ịtarti plaučiuc hipoplaziją. Igimta plaučių hipoplazija formuojasi veikiant aplinkos veiksniams: dèl mechaninio besivystančio vaisiaus plaučio spaudimo (cistinè adenomatoidinè malformacija, diafragmos išvarža ir kt.), dèl pablogejjusios plaučių kraujotakos (Fallot tetrada, Ebstein anomalija) ir kitų priežasčių.

Igimta plaučių hipoplazija sergantiems naujagimiams būna sunkių kvėpavimo sutrikimų: kvejpavimo distreso sindromas, dusulys su cianoze. Išgyvenusiems pacientams kvėpavimo sutrikimai išlieka ir vyresniame amžiuje, jie pasireiškia sunkia lètine plaučiuc liga su dusuliu, lètiniu kvėpavimo nepakankamumu, dažnomis kvejpavimo takų infekcijomis, cianoze po fizinio krūvio. Prognozè blogesnè pacientams, kurie serga ir igimta dešiniojo plaučio hipoplazija. Plaučių hipoplazijos patognominis požymis plaučiuc kompiuterinejje tomogramoje matomas tarpuplaučio poslinkis i pažeisto plaučio pusę [3].

Igyta plaučių hipoplazija yra dažnesnè už igimtą. Smulkiųjų bronchų šakojimąsi, alveolių formavimąsi antenataliniu laikotarpiu ir pirmuosius trejus gyvenimo metus gali sustabdyti infekcija, aspiracija, jonizuojančioji spinduliuoté, skoliozè. Pirmaisiais gyvenimo metais persirgtos infekcijos paskatinta plaučių hipoplazija kitaip vadinama Swyer-James sindromu $[5,6]$.

Swyer-James sindromas dažniausiai išsivysto kaip ankstyvoje vaikysteje persirgtų Mycoplasma pneumoniae, Streptococcus pneumoniae, RSV infekcijų komplikacija. Dèl pažeistos plaučių audinio diferenciacijos pacientams iki $8 \mathrm{~m}$. amžiaus sutrinka pažeisto plaučio kraujagyslių ir paties plaučio augimas. Sindromo klinikinè išraiška - lètinè plaučių liga su būdinga bronchiolių anomalija. Būdingi plaučių radiologiniais tyrimais nustatomi pokyčiai išsivysto per kelis ménesius ar metus po persirgtos infekcijos. Swyer-James sindromo paplitimas daugelyje pasaulio šalių nèra žinomas. JAV medicinos literatūros duomenimis, šiuo sindromu sergantiems pacientams būdinga dažni plaučių uždegimai, švokštimas dèl bronchiolių ligos, krūtinès ląstos ir plaučių asimetrija, patvirtinama radiologiniais tyrimais, bronchų obstrukcijai būdingos spirometrinès kreivès.

Šiame straipsnyje aprašytai pacientei naujagimystèje kvépavimo sutrikimų nebuvo, tačiau plaučių uždegimu ji sirgo beveik kasmet nuo $1 \mathrm{~m}$. 10 mèn. amžiaus. Dažni švokštimai ir bronchiolių obstrukcijos požymiai (pvz.: birzgiantys karkalai plaučiuose) buvo siejami su prasidedančia astma, vèliau buvo pagalvota apie igimtas bronchektazes, cistinę fibrozę.

Nuo $9 \mathrm{~m}$. amžiaus pacientès bronchų astmos simptomų kontrolè buvo nepakankama taikant adekvatú pakopini astmos gydymą, ir tai paskatino nuodugniau ištirti pacientès kvèpavimo takus. Tik plaučių kompiuterinė tomografija, kuria $12 \mathrm{~m}$. amžiaus pacientei buvo nustatyta krūtinès ląstos ir plaučių asimetrija, tarpuplaučio poslinkis ì nesveikojo plaučio pusę pakreipè ligos diagnostiką reikiama kryptimi. Pašalinus patologiškai pakitusią kairiojo plaučio dali, gydant taip pat kaip ir iki operacijos gana gretai pasiekta gera astmos simptomų kontrolè.

Norèčiau priminti gydytojams, gydantiems mažų ir vyresnių vaikų kvépavimo takų ligas, kad po gimimo vaiko plaučiai nesustoja augti ir vystytis. Maži vaikai dažnai serga ūminèmis kvẻpavimo takų infekcinèmis ligomis, taigi yra tam tikra rizika susirgti igyta plaučiu hipoplazija. Negydoma plaučių hipoplazija pasunkina kitos, gretutinès kvejpavimo takų ligos (astmos) gydymą ir pablogina paciento gyvenimo kokybę, atsiliepia paciento sveikatai ateityje.

Aprašytas klinikinis atvejis turètų paskatinti gydytojus ateityje pagalvoti ir apie plaučių hipoplaziją bei savo darbe taikyti informatyviausius plaučiu tyrimo metodus, ypač gydant vaikus, dažnai sergančius pneumonija ir lètinèmis obstrukcinèmis plaučių ligomis.

\section{LITERATŪRA}

1. Kushwaha R.A.S., Verma S.K., et al., Isolated left uppe lobe aplasia and lower lobe hypoplasia with bronchial asthma, The internet Journal of Pulmonary Medicine, 2007, Vol.9, N.1, VISSN:1531-2984, internetine prieiga http://ispub.com/journals/the_internet_of_pulmonary_medicine/volume_9_number_1_8

2. Danila E., Šatkauskas B., Klinikinè pulmonologija, Vaistų žinios, Vilnius 2008, 97-109.

3. Current Paeditric Diagnosis \& Teatment, 13- th edition, eds by W. Hay, Jr.J. R.
Groothuis, A. R. Hayward, M.J. Levin Appleton\&Lange, 1997, p 449-450.

4. T. Chin, G. Natarajan, I. Abdulhamid, Pulmonary Hypoplasia, 2009 internetinè prieiga http://emedicine.medscape.com/article/1005696overview

5. Wood B.P., Swyer- James Syndrome, 2008, internetinè prieiga: http:// emedicine.medscape.com/article/361906-overview

6. Braunscweig M., Gal I., Swyer- James Syndrome, JBR-BTR, 2001; 84(2):57 (Medline) 